\begin{tabular}{ll}
\hline & Jurnal Sains Materi Indonesia \\
Homepage: http:/jusami.batan.go.id & $\begin{array}{l}\text { Akreditation No:21/E/KPT/2018 } \\
\text { Date 9 July 2018 } \\
\text { ISSN 1411-1098 } \\
\text { E-ISSN 2614-087X }\end{array}$ \\
\hline
\end{tabular}

\title{
UTILIZATION OF SLAG POWDER FOR CEMENT SUBSTITUTION BASED ON THE COMPRESSIVE STRENGTH AND PENETRATION OF CHLORIDE IONS
}

\author{
Yasmina Amalia ${ }^{1}$, Syoni Soepriyanto ${ }^{2}$ \\ ${ }^{1}$ Universitas Pembangunan Nasional Veteran Yogyakarta, JL SWK 14, Yogyakarta, 55283 \\ ${ }^{2}$ Institut Teknologi Bandung, Jl. Ganesha No.10, Bandung, 40132 \\ E-mail: yasminaamalia@upnyk.com
}

Received: 26 September 2018

Revised: 4 December 2018

Accepted: 11 December 2018

\begin{abstract}
UTILIZATION OF SLAG POWDER FOR CEMENT SUBSTITUTION BASED ON THE COMPRESSIVE STRENGTH AND PENETRATION OF CHLORIDE IONS. The availability of waste from nickel ore smelting in the form of slag has increased, this is due to the high nickel production to meet the increasing needs for development and for compounding materials for construction materials. This research aims to make a paste from the mixture of Nickel Pig Iron (NPI) slag from PT Indoferro which is used as a substitute for making cement paste. The materials used in this study are cement, nickel slag, water, and zeolite. The cement paste is made with a dimension of $10 \mathrm{~cm} \times 5 \mathrm{~cm}$ with each slag used as an amplifier on the paste with a volume variation of $15 \%, 30 \%, 45 \%$, and $60 \%$. Each material is weighed according to mix design then mixing the materials, after they are homogeneous, they are put into the mold and then let stand for 24 hours until the paste solidifies and hardens, after 24 hours, the paste sample is removed from the mold and treated at room temperature, after the life is qualified, the paste sample is tested. Results of the compression test show that variations of slag addition to the paste mixture giving maximum compressive strength is the $15 \%$ variant for NPI slag. The increase in compressive strength of the slag mixture paste may occur because slag contains cement compounds which can chemically react with Calcium Hydroxide $(\mathrm{CH}) \mathrm{com}-$ pounds as a result of the hydration reaction of cement with water to form a Calcium Silicate Hydrate (CSH) compound from the hydration result between water and cement to increase adhesion and compressive strength on cement paste.
\end{abstract}

Keywords: Nickel Pig Iron (NPI), slag, Calcium Silicate Hydrate (CSH), Calcium Hydroxide (CH).

\section{ABSTRAK}

PEMANFAATAN SERBUK TERAK UNTUK SUBSTITUSI SEMEN BERDASARKAN KUAT TEKAN DAN PENETRASI ION KLORIDA. Ketersediaan limbah hasil peleburan bijih nikel berupa terak sudah semakin meningkat, hal ini disebabkan oleh tingginya produksi nikel untuk memenuhi kebutuhan pembangunan yang semakin meningkat serta untuk bahan unsur pemadu untuk bahan konstruksi. Penelitian ini adalah membuat pasta dari campuran terak Nickel Pig Iron (NPI) dari PT Indoferro yang digunakan sebagai substitusi pada pembuatan pasta semen. Material yang digunakan dalam penelitian ini adalah semen, terak nikel, air, zeolit. Pasta semen dibuat dengan dimensi $10 \mathrm{~cm}$ x $5 \mathrm{~cm}$ dengan masing-masing terak yang digunakan sebagai penguat pada pasta dengan variasi volume $15 \%, 30 \%, 45 \%, 60 \%$. Material masing-masing di timbang sesuai dengan mix design kemudian di lakukan pencampuran bahan setelah homogen, bahan di masukkan kedalam cetakan lalu di diamkan selama 24 jam sampai pasta memadat dan mengeras, setelah 24 jam sampel pasta dilepas dari cetakan lalu dilakukan perawatan pada suhu ruangan, setelah umurnya memenuhi dilakukan pengujian pada sampel pasta. Hasil pengujian tekan menunjukkan bahwa variasi penambahan terak pada campuran pasta yang memberikan kuat tekan maksimum adalah varian 15\% untuk terak NPI. Peningkatan kuat tekan pasta campuran terak ini dapat terjadi karena terak mengandung senyawa sementik yang secara kimiawi dapat bereaksi dengan senyawa Calcium Hydroxide ( $\mathrm{CH}$ )hasil reaksi hidrasi semen dengan air membentuk senyawa Calcium Silicate Hydrate $(\mathrm{CSH})$ dari hasil hidrasi antara air dengan semen yang berperan untuk meningkatkan daya rekat dan kuat tekan pada pasta semen.

Kata kunci: Nickel Pig Iron (NPI), terak, Calcium Silicate Hydrate (CSH), Calcium Hydroxide (CH). 


\section{INTRODUCTION}

Rapid technological and industrial developments apparently have an impact on human life, both positive and negative. Positive impacts are indeed expected by humans in or-der to improve the quality and comfort of life. However, the unexpected negative impacts must be able to be dealt with properly. Industrial and technological waste is one of the negative impacts of technological and industrial developments. To overcome this problem, it is necessary to do waste management so that the impact of environmental pollution can be reduced and even eliminated.

Waste from Blast Furnace extraction of Nickel Pig Iron (NPI) is Slag. Slag that has undergone combustion has elements of lime, silica and alumina which have a chemical com-position no different from natural minerals including hydration materials such as Portland Cement. According to the 2015 Clean Technology Platform, slag usually replaces $35-65 \%$ of Portland cement in concrete. As a result, 50\% replacement of slag with Portland cement in concrete might cause a de-crease of around 0.5 tons of $\mathrm{CO} 2$ [1]. Adjoudj 2014 concluded that when PC replacement rate rose by $30 \%$, the yield stress would increase, but a decrease in plastic viscosity will occur [2]. According to Erdogan 2016, slag can increase abrasion resistance, reduce water, chloride ions and gas permeability [3]. In several studies by Tang (2013) and Darquennes (2013), earlier cracks were more common in concrete without slag than concrete with slag. [4-5] Siddique (2014) states that GGBFS concrete is usually more susceptible to attack of magnesium sulfate than sodium sulfate [6].

With this underlying basis, more serious handling of slag is necessary. The produced slag must be handled or utilized properly as it can potentially cause environmental problems, but it can also be very useful if managed properly and correctly.

Based on the above background, it is considered necessary and important to understand well the management of slag waste so that it can have more values. The results of this analysis are expected to provide solutions to some of the encountered problems with regard to metallurgical waste management problems. This understanding is very useful for the science and cement industry in Indonesia, including its relation to environmental aspects.

From the background and problems above, this study focuses on discussing the substitution of cement with nickel pig iron slag as a substitute for cement paste whose function is able to replace the role of cement in general. With a large silica composition on nickel slag about $41.47 \%$, it is expected that the hydration process occurs between water and cement (cement paste) and will be able to bind the aggregate and form a more perfect interface, hence the destruction of concrete does not occur on the interface, or if there is a breakdown in the interface which requires a relatively high amount of energy, in other words, the concrete strength is high due to the high adhesive power so that the pores in the cement paste or the possibility of pores is very low. This research also aims to find out the strength of slag that it can be said that slag can have its own strength and has value of it so it is used as a substitute for cement. H. Zhao conducted a study that slag cement of $40 \%$ has the highest compressive strength value than cement slag in other mixtures [7]. J.H. Lee (2015) conducted re-search for 6 years and concluded that the addition of slag to $70 \%$ had a higher compressive strength than without slag [8]. A. Younsi, (2013) states that mixing cement slag will be more resistant to carbonation than Portland cement [9].

Therefore, research was chosen with the title "Utilization of Slag Powder for Cement Substitution Based on the Compressive Strength and Penetration of Chloride Ions".

\section{EXPERIMENTAL METHOD Materials and Equipment}

The research experiment began on May 26, 2017. It was started by conducting a mix design from Slag of PT. Indofer-ro, Cement of PT. Holcim Indonesia, and Zeolite from Klaten, Central Java. Samples that have met the curing time were then tested for compressive strength. The highest yield from the compressive strength test was then followed by Chloride Ion Penetration Test.

The equipment used are $\mathrm{X}$-ray fluorescence (XRF) RIGAKU - NEX QC+QuanTEZ for chemical composition analysis, Compres-sion Testing Machine (CTM) with the brand ELE for compres-sive strength analysis, SaltTestr for Chloride Ion analysis.

\section{Procedure}

Preparation of the sample started with mixing the in-gredients and cement for 90-120 seconds, followed by pouring water solution. The mixing process continued until the mix-ture was homogenized sufficiently. The amount of each mix-ture used was sufficient to transmit the specimen. The cyl-inders used were pipe cut with dimensions of $100 \mathrm{~mm}$ in height and $50 \mathrm{~mm}$ in diameter. After that all the specimens were cov-ered with a wet cloth for a night. Then, on the next day, the specimens were removed from the mold and placed in dry conditions until testing.

In this study, two series of mixtures were made, namely cement and slag. Experiments were designed to evaluate the performance of the best mixtures by testing the strength of the pressure and resistance to chloride ions. Experimental variables include curing time, the amount of slag in the mixture, and the presence or absence of zeolite mixture in the sample.

Curing times were 3, 7, 28 and 56 days. After curing time was sufficient, the strength test against pressure was conducted according to ASTM C39/C39M-10 regarding the Stand-ard test method for compressive strength of cylindrical concrete specimens [10]. The best results will be tested for resistance to 
chloride ions with different types of condi-tions according to ASTM C1152/C1152M-04 regarding the Standard test method for acid-soluble chloride in mortar and concrete [11]. Two types of conditions were studied to deter-mine the resistance to chloride ions, i.e. samples immersed in seawater and samples exposed to seawater atmosphere.

\section{RESULTS AND DISCUSSION}

The slag powder used in the experiment is not from min-ing materials. The slag used is the result of the material that has been burned in the Blast Furnace. The slag powder produced is then substituted with cement to make slag cement paste with high compressive strength and low penetration of chloride ions.

The slag powder used in the experiment was not from mining materials. The used slag was the result of the mate-rial that has been burned in the Blast Furnace. The produced slag powder was then substituted with cement to make slag cement paste with high compressive strength and low penetra-tion of chloride ions.

The composition of the compounds contained in slag will affect the characteristics of cement paste. By comparing the composition of compounds in slag, cement, and zeolite, the role of slag and zeolite to substitute cement can be seen. The following XRF data obtained from PT. Indoferro can be seen in table 1 as follows:

\begin{tabular}{llccc}
\hline \multicolumn{5}{c}{ Table 1. Chemical Composition of Compounds } \\
\hline No & $\begin{array}{l}\text { Chemical } \\
\text { Composition }(\%)\end{array}$ & Cement & Slag & Zeolit \\
1 & $\begin{array}{l}\text { Silicone dioxide } \\
\left(\mathrm{SiO}_{2}\right)\end{array}$ & 21,4 & 42,3 & 70,8 \\
2 & $\begin{array}{l}\text { Calcium oxide } \\
(\mathrm{CaO})\end{array}$ & 63,56 & 28,1 & 2,48 \\
3 & $\begin{array}{l}\text { Alumunium trioxide } \\
\left(\mathrm{Al}_{2} \mathrm{O}_{3}\right)\end{array}$ & 6,75 & 8,4 & 15,7 \\
4 & $\begin{array}{l}\text { Magnesium oxide } \\
(\mathrm{MgO})\end{array}$ & 2,52 & 16,8 & 2,04 \\
5 & $\begin{array}{l}\text { Iron trioxide }\left(\mathrm{Fe}_{2} \mathrm{O}_{3}\right) \\
6\end{array}$ & 2,98 & 3,6 & 3,29 \\
Lain-lain & 2,79 & 0,8 & 5,69 \\
\hline
\end{tabular}

The data obtained explain the content of slag, zeolite and cement compounds. In table 4.2 it can be seen that the content of slag and zeolite has similarities with the com-pounds present in the cement content, only the difference is the percentage of the composition in each of these com-pounds. In the percentage, $\mathrm{SiO} 2$ compound in slag and zeolite has a high composition, where $\mathrm{SiO} 2$ compound plays a role to increase the strength of the cement paste. From these data, it can be concluded that the compressive strength of slag cement paste without zeolite has a compressive strength smaller than slag cement paste with zeolite because zeolite has very high $\mathrm{SiO} 2$.

60
Slag and zeolite have low $\mathrm{CaO}$ levels compared to $\mathrm{CaO}$ in cement. In this case, $\mathrm{CaO}$ affects the heat of hydration to form a C-S-H compound, with low levels of $\mathrm{CaO}$ in zeolite and slag capable of reducing the heat of hydration that occurs so that the hardening takes a long time. Compounds in $\mathrm{CaO}$ and $\mathrm{Al}_{2} \mathrm{O}_{3}$ are constituent compounds of ettringite $\left(3 \mathrm{CaO} \cdot \mathrm{Al}_{2} \mathrm{O}_{3} \cdot \mathrm{CaSO}_{4} \cdot 12 \mathrm{H}_{2} \mathrm{O}\right)$. These compounds play a role in reducing heat due to the hydration reaction so that no cracks occur in the cement paste.

$\mathrm{Fe}_{2} \mathrm{O}_{3}$ compounds in slag, cement and zeolite are almost the same. These compounds form C4AF compounds (Tetracalcium Aluminoferrite). C4AF acts to slow down the hydration process.

$\mathrm{MgO}$ compounds cause expansion in the paste. Slag has a higher value than cement and zeolite. But $\mathrm{MgO}$ compounds can be controlled if the compound is bound by silica.

The testing this time was conducted in two stages, before optimization and by optimization, the test before optimization was divided into four mixing times, namely $15 \%, 30 \%, 45 \%$, and $60 \%$ slag. After obtaining the compressive strength results, optimization is carried out by mixing of 30\%, 35\%, 40\%, 45\%, 50\%, $55 \%$, and $60 \%$.

The results of the recapitulation of the paste compressive strength testing will be presented on the compressive test graph aged 3, 7, 28 and 56 days before optimization and the compressive test graph aged 28 and 56 days after optimization in Figures 1 and 2.

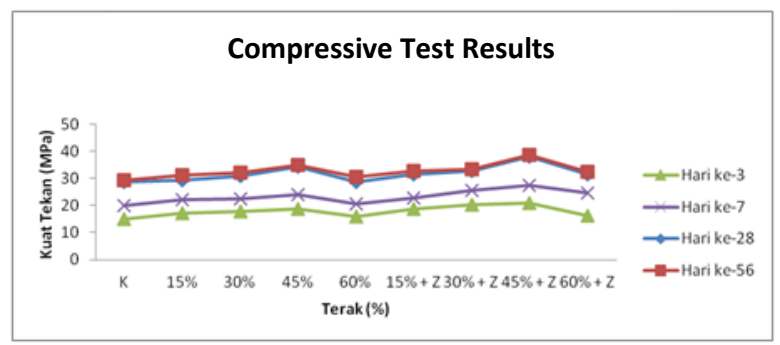

Figure 1. Paste Compressive Strength

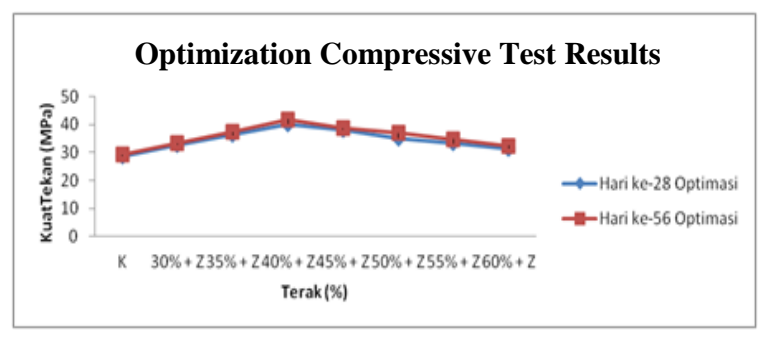

Figure 2. Optimization Paste Compressive Strength

The NPI cement paste is compared with a control cement paste to compare the chloride value entering the paste. Chloride in substitute cement with control cement has almost the same amount for substitution cement having the chloride amount of $0.96 \%$ and $1.39 \%$ with $15 \%$ slag percentage, in control paste cement it has $1.39 \%$ and $1.69 \%$ chloride amount. So it can be said 
that substitute chloride is smaller than the control chloride value. (Figures 3-4)

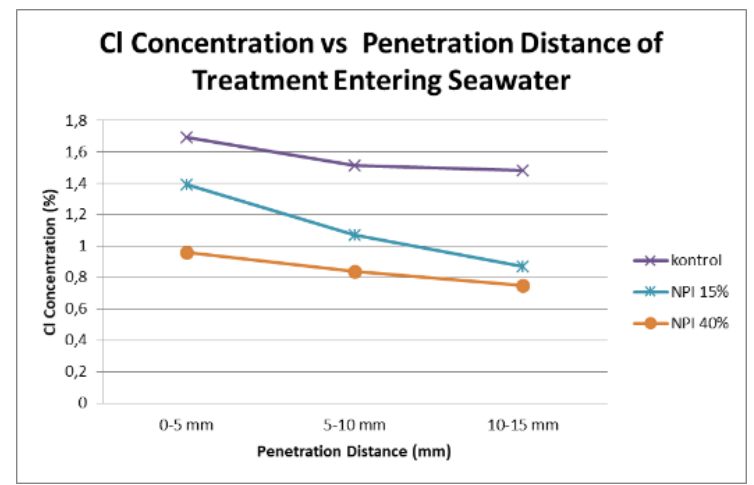

Figure 3. $\mathrm{Cl}$ Concentration of Treatment Entering Seawater

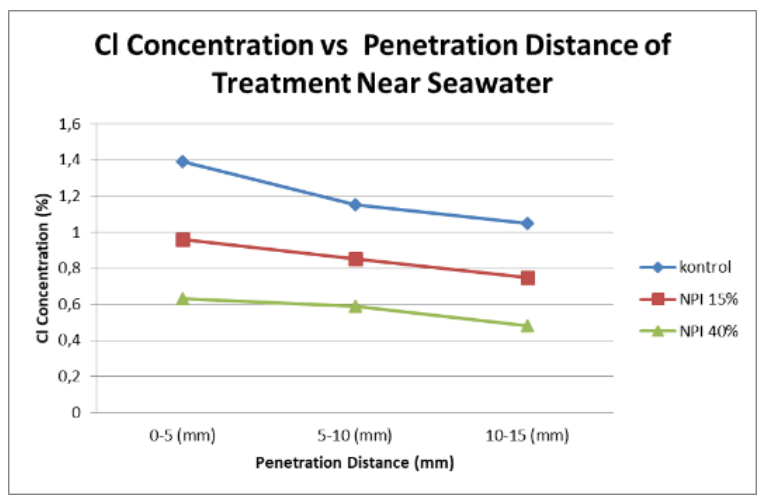

Figure 4. $\mathrm{Cl}$ Concentration of Treatment Near Seawater

\section{CONCLUSION}

Based on the research conducted, it can be concluded that the results of the experimental conditions of substitution compressive strength is $15 \%$ greater than the minimum value of mixing having the same strength as the strength of the cement paste without slag or control paste, namely 14.9 and $18.7 \mathrm{MPa}$. Suggestion for using economical paste substitution and highest compressive strength is with $40 \%$ slag at 28 days able to have compressive strength of $40.1 \mathrm{MPa}$. Substitute cement paste has a better resistance to the Marine Environment than the control paste with a smaller amount of chloride than the control paste, which is $0.96 \%$ and $1.39 \%$.

\section{ACKNOWLEDGEMENT}

Gratitude is expressed to Ministry of Education for the research funding provided, UPN Yogyakarta, ITB Bandung, Prof. Syoni for the support of his knowledge and family for their prayers.

\section{REFERENCES}

[1]. Clean Technology Platform. Internet: http://www.climatetechwiki.org/technology/blast -furnace-slag. [August 04, 2015]

[2]. M. Adjoudj, K. Ezziane, E.H. Kadri, T.T. Ngo, A. Kaci, "Evaluation of rheological parameters of mortar containing various amounts of mineral addition with polycarboxylate superplasticizer," Constr. Build. Mater. vol. 70, pp. 549-559, 2014.

[3]. Erdogan Ozbay. "Utilization and efficiency of ground granulated blast furnace slag on concrete properties - A review." Construction and Building Materials, pp. 423-434, 2016.

[4]. K. Tang, S. Millard, G. Beattie, "Technical and economic aspects of using GGBFS for crack control mitigation in long span reinforced concrete structures," Constr. Build. Mater., vol. 39, pp. 65-70, 2013.

[5]. A. Darquennes, E. Bernard, S. Stephanie, "How to assess the hydration of slag cement concretes," Constr Build. Mater., vol. 40, pp. 1012-1020, 2013.

[6]. R. Siddique, "Utilization (recycling) of iron and steel industry by-product (GGBS) in concrete: strength and durability properties," J. Mater. Cycles Waste Manage, vol. 16, pp. 460-467, 2014.

[7]. H. Zhao, W. Sun, X. Wu, B. Gao, "The properties of the self-compacting concrete with fly ash and ground granulated blast furnace slag mineral admixtures," J. Cleaner Prod., vo. 95, pp. 66-74, 2015.

[8]. J.H. Lee, Y.S. Yoon, "The effects of cementitious materials on the mechanical and durability performance of high-strength concrete," KSCE J. Civ. Eng., vol. 19 (5), pp. 1396-1404, 2015.

[9]. A. Younsi, P. Turcry, A. Ait-Mokhtar, S. Staquet, "Accelerated carbonation of concrete with high content of mineral additions: effect of interactions between hydration and drying," Cem. Concr. Res., vol. 43, pp. 25-33, 2013.

[10]. ASTM C39/C39M-10 Standard test method for compressive strength of cylindrical concrete specimens.

[11]. ASTM C1152/C1152M-04 Standard test method for acid-soluble chloride in mortar and concrete. 